\title{
Preference Changes in New Liberalism: The Impact of Changes of Government on us Trade Negotiations with South Korea and Colombia
}

\author{
Holger Janusch
}

Friedrich-Alexander-University Erlangen-Nürnberg, School of Business and Economics, Findelgasse 7-9, 90402 Nürnberg, Germany

holger.janusch@fau.de

Received 11 April 2017; accepted 4 September 2017

\begin{abstract}
In classical two-level games, international cooperation is less likely when there is large programmatic distance and smaller domestic win-sets as a result of changing preferences. The us trade negotiations with South Korea and Colombia question this hypothesis and emphasize two empirical insights that can be integrated into the twolevel game to improve its explanatory power. First, smaller win-sets due to preference changes can mitigate conflicts of distribution and make cooperation more likely if the negotiators are aware of the smaller win-sets. Second, when negotiators perceive the already achieved bargaining results as a new status quo, former positive sum games can transform into zero sum games, which makes cooperation more difficult, irrespective of the size of the win-sets. Negotiators who perceive conflicts as zero sum games will put more effort into avoiding losses and, as a result, domestic constraints cannot be used as bargaining levers vis-à-vis a foreign country.
\end{abstract}

\section{Keywords}

preference change - international negotiation - two-level game - us trade politics elections

Holger Janusch is assistant professor at the Chair of International Studies at the University Erlangen-Nürnberg, Germany. Previously, he was guest researcher at the School of Advanced International Studies at the Johns Hopkins University, Washington, DC. He holds a doctorate degree in International Relations from the University of Wuppertal. 
In rationalistic approaches of new liberalism such as the two-level game (Putnam 1988; Milner 1997) and liberal intergovernmentalism (Moravcsik 1998; Moravcsik \& Schimmelfennig 2009), actors' preferences are usually assumed to be fixed during international negotiations. However, in domestic as well as international politics, preferences can change quite often and dramatically because of elections, new information or various exogenous events. Yet, fixed preferences are still an often-used assumption. An explanation for this might be that the assumption keeps theory parsimonious. Yet, because changes of government - or changing preferences in general - are common, especially in democracies, the assumption of fixed preferences during negotiations leads to a disregard of domestic politics and with it to misleading conclusions. But even if scholars of new liberalism and bargaining theory consider (implicitly or explicitly) preference changes during ongoing negotiations, they usually circumvent and simplify the theoretical problems by analyzing the bargaining situation as if existing negotiations had never happened and the negotiations had just started under new circumstances (Milner \& Rosendorff 1997; Milner 1997; Hammond \& Prins 2006). Thus, the hypotheses based on the assumption of fixed preferences are merely transferred and applied to the changed bargaining situation as if this were a new case.

Given the central hypothesis of the two-level game - that the smaller the win-sets (the sets of possible agreements which would be ratified by all domestic actors), the more likely international negotiations are to break down scholars deduced that changes of government that decrease the win-sets will reduce the chances for cooperation. A closer look at the us trade negotiations with South Korea and Colombia, however, shows that changes of government which affected the win-sets in a similar way in both cases had different impacts on the ongoing negotiations. While these different effects can be dismissed as empirical ideographic singularity, this article seeks to solve the empirical puzzle by considering two missing aspects learned from the case studies. First, international negotiations are dynamic conflictual processes and not as static as often assumed in new liberalism and bargaining theory. Second, preference changes due to elections do not only affect the bargaining space (which is called the intersection of win-sets in the two-level game), but also the negotiators' perception of conflicts on the basis of already achieved bargaining results.

The aim of this article is to analyze the manifold effects that preference changes can have on two dimensions of international negotiations: the probability of cooperation and the distribution of gains. This is interesting not only for new liberalism but also for other rationalistic approaches, such as bargaining theory and veto player theory. After presenting the state of research, the us trade negotiations with South Korea and Colombia serve as analytical narratives that question the classical hypotheses of the two-level game. The 
narratives highlight two factors - conflict intensity and negotiators' perception on preliminary bargaining results - that have been neglected in two-level games but can help to explain the effects of preference changes on negotiations. These two aspects will then be integrated in the two-level game not only for a better understanding of the empirical cases, but also to improve the explanatory power of the two-level game.

\section{New Liberalism and the Assumption of Fixed Preferences}

New liberalism can be understood as a rationalistic approach to explain foreign policy making by looking at domestic politics. While new liberalism developed as a critique of the unitary actor assumption of neorealism and neoliberal institutionalism, it is - like neorealism and neoliberal institutionalism - still based on assumptions of rationality. In new liberalism, foreign policy making is often separated into two phases: formation of state preferences and international bargaining between state actors. In the first phase, New Liberals refer to the approaches of New Political Economy, such as the theory of collective action (Olson 1965), to explain how societal interests form state preferences. New liberalism can, therefore, explain different preferences between states and also changes in state preferences over time. But for the sake of simplicity and parsimony, fixed state preferences are generally assumed once international negotiations have begun. In this second phase, bargaining theories are used to explain the outcome of international negotiations (Moravcsik 1997, 1998; Moravcsik \& Schimmelfennig 2009). In this way, New Liberals often ignore preference changes based, for example, on changes of government during international negotiations and thereby disregard the impact of domestic politics on international negotiations. ${ }^{1}$

Yet, preference changes have not been neglected completely in new liberalism. Some scholars have considered elections in their theoretical models. Tabellini (1990) analyzes how international cooperation affects budget deficits under electoral uncertainty. Morrow (1991) models the effects of endogenous elections in us-Soviet arms control negotiations. In this model, the us administration is willing to give more or fewer concessions in arms control negotiations, depending on its chances of re-election. Lohmann (1993) analyzes the interaction between political competition of domestic parties and international cooperation. She considers exogenous elections in the form of a

1 For a definition and critique of preference-based approaches, see Hausman (2011); and Rizvi (2001). For more about preference formation, see Kim (2015); and Koenig-Archibugi (2004). 
random lottery. Smith and Hayes (1997) modify a two-level game in which elections serve as an indirect ratification mechanism. They argue that the voters' choice is between an agreement that the current government can reach and one that an alternative government could reach, rather than the status quo. In an empirical study, Frye and Mansfield (2004) prove that democratic governments are more likely to liberalize trade shortly after election because trade liberalization causes short-term costs for specific groups and only generates widespread benefits for consumers in the long-run. While all these approaches model how electoral uncertainty affects the behavior of actors in domestic and international politics, they do not explain the effects of preference change on ongoing negotiations.

In contrast, Milner and Rosendorff (1997) developed a two-level game to analyze how the probability of cooperation and terms of an agreement vary when the degree of divided government changes because of elections during the ratification phase after an agreement has been signed. They argue that the probability of negotiation failure rises with increasing division in government. Although Milner and Rosendorff (1997) present interesting results, their model is problematic, because changes of government - and therefore preference changes - are only possible during the ratification phase and renegotiation of already signed agreements are excluded. With these assumptions, the effects of preference changes on continuous negotiations cannot be analyzed. Similarly, many New Liberals as well as scholars of veto player theory make a clear cut and analyze the changed bargaining situation as a result of a preference change as if it were a completely new negotiation or they analyze how changes of government affect the chances for cooperation in general, and concentrate less on specific continuous negotiations (König 2006; Milner 1997; Hammond \& Prins 2006). The effects of already established conflicts, previously used bargaining tactics, and already achieved bargaining results are left aside.

A theoretical gap of new liberalism (as well as veto player theory and rationalist bargaining theory) is the missing analysis of effects that preference changes can have on negotiations understood as dynamic and ongoing processes and not as a series of individual situations that can simply be separated from each other. Furthermore, conflicts already manifested and progress already made prior to a preference change have also been neglected in new liberalism as well as veto player theory. ${ }^{2}$ A more specific analysis of preference

2 Yet, there are several theoretical models that are interesting in this context. Downs et al. (1998) analyze how the strategy of admitting new members sequentially to multilateral agreements affect the evolution of cooperation and depth of integration. Mertha and Pahre 
changes that sees negotiation as a conflictual and continuous process is important, because it is common for preferences of state actors to change dramatically for various reasons, such as elections or new information, during international negotiations. In addition, Pahre (2004) shows with the help of a two-level game - even though he does not focus on preference changes that small changes in the preferences of different non-median actors, such as a key filibuster member in the Senate, can already lead to large institutional changes. While our study dismisses the assumption of fixed preferences, the assumption of exogenously given preferences remains in place, to prevent an overly complex theory. In fact, various economic approaches already acknowledge endogenous preference changes (Bradley 2009), such as Bayesian models of adaptive preferences (Gerber \& Jackson 1993; Martin \& Quinn 2007), models of non-informational preference change (Dietrich \& List 2011), and prospect theory (Tversky \& Kahneman 1992; Trampusch 2014). These can be integrated into new liberalism, but are not the focus of this article.

\section{Classical Hypotheses of the Two-level Game Regarding Preference Changes}

In two-level games, national governments negotiate to reach a tentative agreement at the international level that satisfies the interests of domestic pressures. At the same time, the governments negotiate with their constituencies at the domestic level to ensure ratification of the international agreement. A key feature of the two-level game is the so-called win-set: the possible set of arrangements at the international level that would be approved at the domestic level (Putnam 1988). The larger the win-sets at the domestic level, the more likely is cooperation at the international level, other conditions remaining the same. "Thus, agreement is possible only if those win-sets overlap, and the larger each win-set, the more likely they are to overlap. Conversely, the smaller the winsets, the greater the risk that the negotiations will break down" (Putnam 1988: 438). Following this argument, if preference changes that make interests more heterogeneous between actors and thereby decrease the domestic win-set should occur during negotiation, the probability that the domestic and foreign

(2005) develop a model in which negotiators can anticipate that an agreement will only be implemented partly. Bearce et al. (2009) show how the shadow of the future affects actors' decisions at the pre-bargaining phase to finally begin negotiations. Ishiguro (2016) analyzes how institutional reforms that increase the power of the prime minister and decrease the power of congress and ministry bureaucrats affect the chances of trade cooperation. 
win-sets do not overlap will increase, which is why international cooperation becomes less likely. Conversely, if preferences, for example, due to a change of government become more homogeneous and increase a domestic win-set, cooperation becomes more likely, because the domestic and foreign win-sets are more likely to overlap. From a probabilistic point of view, the likelihood of cooperation decreases when changes lead to more heterogeneous preferences.

Yet, it is important to note that in this hypothesis, preference changes have no effect on the probability of cooperation when an intersection of the winsets has already existed and remains in existence, or when no intersection of the win-sets existed even under complete information. The reason for this is that rational actors do actually cooperate independently of the size of the intersection, as long as the win-sets overlap and all actors can increase their utility. In contrast, many scholars assume (often implicitly) that a decreasing win-set lowers the probability of cooperation even if a win-set and the intersection of win-sets respectively does not dissolve completely. Tsebelis (2002: 21-22) highlights three explanations (regarding domestic politics between veto players) for this correlation. First, the bigger a win-set, the more policy options exist that can defeat the status quo and, therefore, the more susceptible to change is the status quo. Second, the bigger the win-set, the more likely does a subset of the win-set fulfill external constraints. Third, it is more likely that transaction costs exceed the gains from slight changes of the status quo when win-sets are small. Our study is focused, in particular, on the Tsebelis' hypothesis because most scholars usually (implicitly) have this hypothesis in mind when analyzing individual cases.

Furthermore, preference changes can have an effect on the distribution of gains. According to the Schelling conjecture, a smaller win-set can be a bargaining advantage for governments vis-à-vis foreign countries, because governments can more credibly refer to their tied hands due to domestic constraints in order to receive more concessions (Putnam 1988; Schelling 1960). In this sense, a divided government in which the executive and legislature are represented by different parties increases the executive's bargaining leverage vis-à-vis the foreign government. Therefore, preference changes that decrease a domestic win-set increase the bargaining power and therefore the gains from cooperation. This conjecture is supported by various theoretical models and empirical studies (Iida 1993, 1996; Milner \& Rosendorff 1997; Dorussen \& Nanou 2006; Hug \& König 2002; Smith \& Hayes 1997; for a model on endogenous domestic constraints, see Chapman et al. 2013). Yet many scholars question the Schelling conjecture (Milner 1997) and show that domestic constraints can be a bargaining advantage but also a disadvantage, depending on the political institutions (Pahre 2006, 1997), the preferences of domestic actors, the position of the 
status quo (Hammond \& Prins 2006; Trumbore 1998), the distribution of power between the negotiators and domestic constituents (Mo 1994), or the type of constituency (local or national) (Tarar 2005).

\section{us Trade Negotiations with South Korea and Colombia}

While the two-level game will be used here as an analytical tool, us negotiations with South Korea and Colombia over free trade agreements (FTA) will serve as case studies and be employed as narratives. The combination of rational choice theory and the narrative form helps to identify and explore specific causal mechanisms that shaped actors' preferences and actions and thus generated a particular outcome. If the empirical observations do not confirm the hypotheses (as will be shown), instead of simply rejecting a model, the narrative can help to adjust the theoretical model (Bates et al. 1998, 2000; Pahre 2005). The us trade negotiations with South Korea and Colombia were selected because preference changes due to changes of government in the United States had similar effects on the domestic win-set in both cases, but led to different effects on the negotiation outcome in terms of the probability of cooperation (and risk of negotiation breakdown, respectively) and distribution of gains. Both narratives, thus, present a synchronic comparison inspired by the method of difference (Ragin 1987). The comparison of the narratives helps to identify the decisive factor that explains the different effects of the same preference changes. The author is aware of a possible selection bias and that the empirical results cannot be generalized and are limited to the cases. Yet, the comparison of the narratives can help to improve and adjust the theoretical model. The following narratives are based on documents such as articles in newspapers and congressional reports, secondary literature and expert interviews with former us trade representatives, us chief negotiators, and senior staff members of Congress. ${ }^{3}$

The evaluation of preference changes in the United States is based on the formulated policy positions of the particular administration and leadership in Congress regarding free trade agreements in general and demands to renegotiate specific issues (labor provisions in the case of Colombia and automobiles in the case of South Korea). The assumed preference changes conform to various studies that come to three conclusions. First, Republicans are generally more supportive of free trade than Democrats. Scholars refer to ideological

3 To ensure anonymity, interviewees are referred to as 'senior officials'. The case studies are part of a research project covering all bilateral US FTA negotiations. 
differences, affiliated interests and respective constituencies to explain this partisan divergence (Bohara et al. 2005; Hiscox 1999; Im \& Sung 2011; Weller 2009; Janusch 2015b). Second, the President, regardless of his party affiliation, supports free trade more than Congress. The reason for this is that the President is elected by a nationwide electorate and represents national interests. In contrast, members of congress are more closely committed to the particular interests of their smaller constituencies that are more likely to be protectionist (Carter \& Eden 1999; Mansfield et al. 2002; Rankin 2006; Karol 2000). Third, the same applies to Congress itself. Senators due to their larger constituencies and longer terms are generally more in favor of free trade than Representatives of the House (Sussman \& Daynes 1995).

\section{Beginning of the Trade Negotiations}

In May 2004, the Bush administration began negotiations over a regional FTA with the Andean countries, including Colombia, Ecuador and Peru. While the Bush administration made significant progress with Peru over time, the talks with Ecuador and Colombia proved difficult. In November 2005, the administration cancelled the regional FTA negotiations and began bilateral talks with each Andean country separately (Janusch 2015a). In the case of Colombia, negotiations began in January 2006. Controversial issues included market access for agricultural products and textiles, intellectual property rights (IPR), and sanitary and phytosanitary measures. ${ }^{4}$ In August, both governments finally resolved all differences and the path was free for signing the agreement. ${ }^{5}$

Two months earlier, the Bush administration and the South Korean government had begun official FTA negotiations. In these talks, the main issues were market access for agricultural products, especially beef, and automobiles, but IPRs and trade remedy measures also created intensive conflict (Cooper et al. 2011: 28-30). From the beginning, both governments were under time pressure to find an agreement by the beginning of April 2007. Otherwise, the deal would not meet the deadline for signing before the expiration of the Trade Promotion Authority (TPA) at the end of June 2007. The TPA allows Congress to approve FTAs under fast track procedures. This means that a bill can come to the floor without action by the leadership, and Congress can only vote up or down without making amendments and under specific time limits, so long as

4 Inside U. S. Trade (2006): Portman Hopes for Peru FTA Approval this Year; Colombia Resumes Talks, 27.01; Inside U. S. Trade (2006): U.S., Colombia Set New Meeting for Mid-February after Weeklong FTA Session, 07.02.

5 Inside U. S. Trade (2006): White House Notifies Congress It Wants to Sign Colombia FTA, 25.08. 
the us administration has fulfilled specific negotiation objectives and consultation procedures.

\section{Midterm Elections in 2006}

In November 2006, the Democrats won the midterm elections and thereby the majority in the House (233 Democrats vs. 202 Republicans) and the Senate (49 Democrats plus 2 Independents vs. 49 Republicans). The Democratic caucus gained 30 seats in the House and 6 seats in the Senate. Hence, the Bush administration could no longer rely on a Republican leadership in Congress. This preference change of Congress decreased the win-set of the United States because of two reasons. First, Democrats in general had a more skeptical position on free trade than Republicans. Second, Democrats support stronger labor provisions in trade agreements and are more open for market access restrictions in trade agreements. Backed by the trade unions, the Democratic leadership in Congress demanded improvements related to the provisions for labor standards and automobiles. ${ }^{6}$ In the case of Colombia, the Democrats pointed

6 This assessment of the midterm elections' impact on the 11oth Congress' preferences is supported retrospectively by the voting behavior in Congress. The partisan votes regarding the United States-Peru Trade Promotion Agreement Implementation Act (H.R. 3688), the resolution relating to the consideration of the bill to implement the United States-Colombia Trade Promotion Agreement (H.R. 1092), and the Trade and Globalization Assistance Act of 2007 (H.R. 3920) demonstrate that the new Congress was more skeptical towards free trade and supported stronger protection for workers. The House passed the United States-Peru Trade Promotion Agreement Implementation Act on a 282-132 vote, whereby 109 Democrats and 176 Republicans voted for the bill, while 116 vs. 16 voted against it. From ${ }^{1}$ Democrats who replaced a Republican in the House, 20 congressmen voted against the bill. The two Republicans who replaced a Democrat from the 109th Congress voted for the bill. The Senate passed the bill by a vote of 77-18. 29 Democrats and 47Republicans voted for the bill, while 16 vs. 1 voted against it. Five of six Democrats who replaced a Republican voted against the bill. The resolution to implement the United States-Colombia Trade Promotion Agreement comprised an amendment to the Rules of Change to eliminate time limits and constraints on fast-track debates for the FTA with Colombia. After passing the resolution, the Democratic leadership in the House could decide when to vote on the FTA. The House passed the resolution by a vote of 224-195 strongly along party lines. 218 Democrats and 6 Republicans voted for the resolution, while 10 vs. 185 voted against it. 28 of 31 Democrats who had replaced a Republican voted for the resolution. The two Republicans who toke over seats from Democrats voted against the resolution. The Trade and Globalization Assistance Act included a reauthorization and extension of the Trade Adjustment Assistance. The Trade Adjustment Assistance is a program that supports workers who lost their jobs due to trade agreements. The Senate never passed the bill. The House passed the bill by a vote of 264-157. 226 Democrats and 38 Republicans voted for the bill, while 2 vs. 155 voted against it. 29 of the 
out that they were not willing to ratify the FTA if Colombian workers' rights were not strengthened. ${ }^{7}$ Despite the Democratic critique, the Bush administration and the Uribe government signed the FTA in November, shortly after the elections. Yet, both executives had already stated that they were open to further concessions vis-à-vis the Democrats regarding labor standards to ensure the approval of the FTA. ${ }^{8}$

With the accession of the newly elected Congress in January 2007, the Bush administration, Republicans, and Democrats began negotiations over a new trade agenda, especially with regard to labor standards, but also to market access for automobiles. The Bush administration, however, did not delay the FTA negotiations with South Korea because of the upcoming deadline set by the TPA. Under this time pressure, the Bush administration and the South Korean government came to an agreement - except for the Korean ban on us beef imports, which was linked to the FTA but not a formal part of it - at the beginning of April, so that the FTA could be presented to Congress in time and signed before the TPA expiration (Ju 2009: 154). ${ }^{9}$ A month later, the Bush administration and Democrats finally concluded a deal, the so-called May 10 Agreement (Janusch 2016). The Bush administration was aware of the smaller win-set due to the elections, for which reason it accepted most of the Democratic demands. Furthermore, the Bush administration agreed to renegotiate the provisions for automobiles in the FTA with South Korea, which had not yet been signed. ${ }^{10}$

In June 2007, the Bush administration and the Uribe government met for renegotiations over the labor provisions. Because the Uribe government was also aware of the smaller win-set, both executives quickly (by the end of the month) agreed on protocol supplements in accordance with the May 10 Agreement. In Colombia, ratification proceeded without difficulty. The Colombian congress had already ratified the FTA with a large majority in June and approved the protocol supplements in September and October (Villarreal 2011). In the case of South Korea, the government rejected renegotiations at the beginning, but both countries started renegotiations in June. Yet, the South

31 Democrats who replaced a Republican voted for the bill, while the two Republicans who replaced a Democrat voted nay.

7 Interview with senior official of the Office of the United States Trade Representative (USTR), 23.05.2012, Washington DC.

8 Inside U. S. Trade (2006): Colombia Official Hints Additional FTA Concessions after Elections, 20.10; Inside U. S. Trade (2006): Deputy USTR Signals Possible Labor Steps to Pass Colombia FTA, 24.11.

Inside U. S. Trade (2007): U.S., Korea Conclude FTA without More Rice Access, Beef Unresolved, 02.04 .

$10 \quad$ Inside U. S. Trade (2007): Schwab, Congress Announce Labor, Environment FTA Deal, 11.05. 
Korean government saw the already agreed deal as a new negotiating basis, which is why it perceived the renegotiation as a kind of zero sum game. ${ }^{11} \mathrm{In}$ the end, the South Korean government accepted the new provisions for labor standards, but obtained concessions regarding IPRs for pharmaceutical products as a side payment. Furthermore, the Bush administration withdrew its demands regarding automobiles. The Democratic leadership, however, reminded the administration to renegotiate market access for automobiles. ${ }^{12}$

Despite the protocol supplements, the Democratic leadership in Congress still rejected the FTA with Colombia and insisted on improvements in Colombia's national labor laws and a decrease of homicides against trade unionists. ${ }^{13}$ Thereupon the Bush administration and the Colombian government signaled their willingness for further talks, which began in August 2007. Despite this willingness, the Democrats never presented a list with concrete demands. As an agreement was still not attainable in April 2008, the Bush administration introduced the FTA in Congress without the acceptance of the Democratic leadership, to obtain approval by Congress before the upcoming presidential elections. Because the deal was signed under the TPA, the Bush administration hoped that it would lie inside the win-sets and the Democrats would approve the deal, even if the Colombian government had not by then changed any national labor laws. President Bush also tried to gather support by emphasizing that a rejection of the FTA would hurt foreign relations with Colombia and the fight against coca production and drug traffic. ${ }^{14}$ Yet, in the same month, the Democratic-dominated House approved the Fast Track rules change that nullified time restrictions under the TPA. From then on, the Democratic leadership could decide when to approve the FTA with Colombia. This course of action intensified the conflict (Villarreal 2011: 1-2; Beittel

11 Inside U. S. Trade (2007): Korean Officials Reject FTA Renegotiation; Auto Issues Linger, 18.05; Inside U. S. Trade (2007): USTR to Meet with Korea, Discuss FTA Template Changes, 19.06; Inside U. S. Trade (2007): Korean Official Takes Hardline on U.S.-Korea FTA Renegotiation, 28.09 .

12 Inside U. S. Trade (2007): Schwab, House Leadership Clash over Demands for Korea FTA Changes, 06.07; Inside U. S. Trade (2007): U.S. Accepts Two FTA Changes as Korea Accepts Labor, Environmental Deal, o6.o7; Interview with senior official of the USTR, 07.03.2012, Washington DC; Interview with senior official of the USTR, 14.05.2012, Washington DC.

13 Inside U. S. Trade (2007): Rangel, Levin Say Conceptual Agreement not Enough for Colombia, 11.05 .

14 Inside U. S. Trade (2008): Bush Submits Colombia FTA Bill for Congress to Receive April 8, 07.04. 
2011: 38$) \cdot{ }^{15}$ However, the Bush administration, the Colombian government and Democrats continued negotiations over labor reforms. ${ }^{16}$

Because the FTA with Colombia was signed before the FTA with South Korea, and Congress traditionally approved trade agreements in the sequence of their signing, the FTA with South Korea remained in the waiting loop as long as there was no agreement with Colombia. Yet, Democrats had warned in autumn 2007 that Congress would approve the FTA only if South Korea was willing to renegotiate the terms regarding automobiles. In addition, the lifting of the import ban on us beef imports was still an issue. ${ }^{17}$ In December 2007, Lee Myung-bak was elected the new president of South Korea. Like his predecessor, President Roh Moo-hyun, he was a strong supporter of the FTA. Furthermore, Lee's Saenuri party also won an absolute majority in the elections in April 2008. While the Minju party, which had previously held the majority, was divided with regard to the FTA, the Saenuri party uniformly supported the FTA. In addition, the Minju Nodong party, which strictly opposed the FTA, lost many seats. Thus, the win-set in South Korea increased after the parliamentary elections (Cooper et al. 2011: 10-11). ${ }^{18}$ While the increased win-set would have lowered the bargaining leverage of the Korean government in renegotiations, President Lee (as well as President Bush) still saw the signed agreement as the new status quo and rejected renegotiation for automobiles. However, he was willing to solve the dispute over the beef import ban that was still open.

Shortly after the elections in April, President Lee agreed to the complete lifting of the import ban. In return, President Bush promised to bring forward the FTA in Congress even if Democrats still demanded renegotiation. ${ }^{19}$ However, the arrangement on beef was only of limited duration; the Lee administration re-imposed a partial import ban in June after massive public protests. This reaction intensified the conflict with the Bush administration and Congress, which insisted on the lifting of the import ban - otherwise the FTA would be

15 Inside U. S. Trade (2008): House Approves Fast-Track Rules of Change for U.S.-Colombia FTA, 11.04; Inside U. S. Trade (2008): Administration Keeps up Public Fight on Colombia; no Real Talks yet, 18.04 .

16 Inside U. S. Trade (2008): Grassley Signals Flexibility on TAA, Uncertainty on FTA Link Remains, 16.05.; Inside U. S. Trade (2008): Colombian Trade Minister Expresses Frustration on Labor Demands, 19.09 .

Inside U. S. Trade (2007): Korea Holds off on U.S. Beef Inspections; Japan Signals Easing of Limits, 17.08; Inside U. S. Trade (2008): Schwab Turns up Rhetoric on Colombia FTA, Top 2008 Trade Priority, 18.01.

18 Interview with senior official of the USTR, 07.03.2012, Washington DC.

19 Inside U. S. Trade (2008): Schwab Says Bush Administration Intends to Submit Korea FTA in 2008, 25.04 . 
not ratified. Because of the continuing protests, President Lee threatened to impose a complete ban on all kinds of us beef. ${ }^{20}$ Thus, both governments had their hands tied by public threats and a solution seemed difficult. ${ }^{21}$ In this deadlock, the us beef industry proposed a voluntary agreement that recognized the partial import ban. Both governments accepted the voluntary agreement (Cooper et al. 2011; Koo \& Jho 2012). ${ }^{22}$ Because an approval of the FTA in Congress was not possible before the us elections in November 2008, and Democratic presidential candidate Barack Obama had already announced renegotiation of the provisions for automobiles, the Lee government wanted to ratify the agreement as soon as possible to strengthen its bargaining position in possible renegotiations. The Minju party, however, was opposed to this course of action and prevented a vote. ${ }^{23}$

Following the classical hypothesis of the two-level game, preference changes that lead to a smaller domestic win-set decrease (increase) the probability of cooperation (risk of a negotiation breakdown) but also create a bargaining advantage and distribute the gains in favor of the country with the smaller domestic win-set. The Democratic takeover after the midterm elections reduced the size of the win-set in both cases in a similar way. Yet, it had different effects on the risk of a negotiation breakdown and distribution of gains.

In the case of Colombia, the Bush administration and the Uribe government quickly signaled their willingness for renegotiation after the midterm elections because they were aware of the smaller win-set due to the Democratic-led Congress, which is why no intensive conflict arose. At first glance, the concessions made by the Colombian government seem to confirm the Schelling conjecture. Yet, these concessions were not in the interest of the Bush administration, for which reason the domestic constraint cannot be seen as a bargaining lever used by the domestic executive vis-à-vis the foreign country. In contrast, the negotiations with South Korea became more conflictual

20 Donga (2008): President Lee Vows to Disallow Imports of Old U.S. Beef, 19.06; Inside U. S. Trade (2008): Korea Backs out of Deal Opening Market to U.S. Beef amid Protests, 06.06; Inside U. S. Trade (2008): U.S., Korea Resume Beef Negotiations; U.S. Signals Flexibility on Age Cap, 13.06; Ramstad, Evan; Park, Sungha (2008): “South Korea's Lee Vows Changes after Flap over U.S. Beef," Wall Street Journal, 20.06.2008.

21 Interview with senior official of the USTR, 07.03.2012, Washington DC. Interview with senior official of the USTR, 06.04.2012, Washington DC. Interview with senior staff member of Congress, 14.05.2012, Washington DC.

22 ввс News (2008): "South Korea to Allow us Beef Back in," 25.06.2008. For more about the prehistory of the Us-South Korea beef dispute, see Jho and Koo (2012).

23 Hyun-kyung, Kang (2008): "Assembly in FTA Conflict," Korea Times, 18.12; Inside U. S. Trade (2009): Korea FTA Appears Set for February Passage in Korean Assembly, o9.01. 
immediately after the midterm elections because the South Korean government saw the already achieved results as a new bargaining basis. This changed perception transformed the conflict of distribution (positive sum game) into perceived goal conflict (zero sum game). This seems to confirm the classical hypothesis that smaller win-sets increase the risk of a negotiations breakdown. Yet, the causal trigger was not some kind of transaction cost or external constraint but the transformation of the perceived conflict. Because of this transformed conflict, the South Korean government was able to demand a concession from the United States in return for each concession it had made itself.

The later conflict between the Bush administration and Democrats that led to the change of the TPA rules seems to be not immediately caused by the preference change, but more a result of the time pressure and misjudgment of the Bush administration. Because the Bush administration was worried that the FTA would never be approved under a Democratic president or its terms might be changed, it hoped that the deal would lie inside the win-set and finally be accepted by Democrats under the fast track procedures. That the Democrats had never presented a list with concrete demands and had changed the TPA rules, suggests that either the Democrats hoped to reach a better agreement after the upcoming presidential elections or the win-set for an FTA with Colombia had dissolved after the midterm elections. In the latter case, the repetition of the prospect of signing an FTA after improvements of labor reforms was just a friendly way to postpone any real talks.

The elections in South Korea demonstrate two aspects. First, the Korean government did not lose any bargaining leverage despite the increasing domestic win-set to its disadvantage, because it took the already signed deal as a new negotiation basis and perceived the negotiations as zero sum game. Second, the dispute over beef demonstrates that a larger win-set does not necessarily increase the chances of cooperation. After its inauguration, the Lee government agreed to lift the beef import ban, resulting in domestic protests. This domestic conflict spread over quickly to the international level. A breakdown of negotiations could only be prevented because the us beef industry proposed a voluntary agreement under which the tied hands of both governments could be freed.

\section{Presidential Elections in 2008}

In November 2008, Obama was elected as the new President and the Democrats kept and expanded their majority in the House (257 Democrats vs. 178 Republicans) and the Senate (57 Democrats plus 2 Independents vs. 41 Republicans). The Democrats gained 25 seats in the House and 8 seats in the Senate. It can be assumed that the domestic win-set increased because the ideal 
points of the Obama administration and Democratic-led Congress converged. First, President Obama was less supportive of free trade than President Bush and, therefore, took a skeptical stance towards free trade comparable to the Democratic-led Congress. Second, President Obama supported the demands by the Democrats for renegotiation of labor provisions and automobiles. In the case of South Korea in particular, the Obama administration in contrast to President Bush was willing to renegotiate the provisions for automobiles. Thus, the possible set of agreements that would be approved domestically in the United States increased to a certain extent after the elections in 2008. While the ideal points of the Obama administration and Congress converged, it is reasonable to assume that the intersection of the win-sets for the FTA with Colombia and South Korea decreased to some extent. The reason for this is that the ideal points of the Obama administration and Congress diverged further from the ideal points of the Colombian and Korean governments. ${ }^{24}$

In spring 2009, the Obama administration and Democrats signaled the compilation of a list of demands for the improvement of workers' rights in Colombia so that Congress would approve the FTA. In the case of South Korea, the FTA negotiations were at risk after the election of President Obama because the South Korean government thought both countries had already signed a final deal. ${ }^{25}$ In May 2009, the South Korean government also signaled that it would be willing to renegotiate the agreement so that the Us Congress would ratify the FTA. ${ }^{26}$ Yet, despite the commitments that President Obama repeated in his State of the Union Address in January 2010, the FTAs had only a low priority for the Obama administration, for which reason the renegotiation with South Korea did not gain momentum until June 2010 (Cooper et al. 2011). ${ }^{27}$

24 The vote on the American Recovery and Reinvestment Act of 2009 (H.R. 1) that included also an extension of the Trade Adjustment Assistance supports the assessment of the elections' impact on the preference changes of the President and the 111th Congress. However, it should be noted that the main issue of the bill was a stimulus package for the us economy, for which reason it can be seen only to a certain degree as an indication for the trade preferences of the President and Congress. The House passed the bill by a vote of 244-188. 244 Democrats and o Republicans voted for the bill, while 11 vs. 177 voted against it. 21 of the 24 Democrats who replaced a Republican voted for the bill. The Senate passed the bill on a vote of 61-37.56 Democrats and 3 Republicans voted for the bill, while o vs. 37 voted against it. All six Democrats who had replaced a Republican voted with yea.

25 Interview with senior official of the USTR, 07.03.2012, Washington DC.

26 Inside U. S. Trade (2009): Obama, Lee Commit to Work for Progress on Korea-U.S. FTA, 03.04.

27 Inside U. S. Trade (2010): Obama Announces Export Changes, Details New Initiative, 11.03; Inside U. S. Trade (2010): Korean Minister Says USTR not yet Able to Propose Solutions for 
The Obama administration hoped to reach an agreement with South Korea by the G2o summit in Seoul in November, shortly after the midterm elections. In the negotiations with Colombia, the administration had also made no progress before the midterm elections in November 2010 (Villarreal 2011: 27). ${ }^{28}$ In September, the Obama administration, however, announced that it would bring forward a list with concrete demands after the elections. ${ }^{29}$ Before the Us midterm elections, congressional and presidential elections had been held in Colombia (March and May 2010). Uribe's party and his successor, former secretary of defense Juan Manuel Santos, won the elections. Thus, the trade preference of the Colombian government did not change and the win-set changed only marginally (Villarreal 2011: 17).

The election of President Obama reduced the programmatic distance towards Congress due to more similar stances regarding free trade in general and common demands for renegotiations regarding labor standards and automobiles. While the domestic win-set in the United States increased, the intersection of the win-sets at the international level decreased to a certain degree because of the increasing programmatic distance between the us government on the one hand and the Colombian and Korean governments on the other. In comparison with the Bush administration, the FTA negotiations had a lower priority for the Obama administration, which is why the negotiations made no progress and remained in a deadlock. A further explanation for this deadlock could be that ratification of the FTA with Colombia (which was next in line) by the Democratic-led House seemed difficult, if not impossible, when assuming that still no intersection of the win-sets existed, for which reason the Obama administration did not bring forward the FTA negotiations.

\section{Midterm Elections in 2010}

In November 2010, the Democrats kept their majority in the Senate (51 Democrats plus 2 Independents vs. 47 Republicans), but lost 6 seats. Furthermore, the Republicans gained 64 seats and won the majority in the House (193 Democrats vs. 242 Republicans). It can be assumed that the ideal points between the Obama administration and the House under Republican

FTA, 21.05; Inside U. S. Trade (2010): White House Says Obama Statement on Advancing U.S.-Korea FTA Will Kick off Bilateral Negotiations, 27.06.

28 Inside U. S. Trade (2010): Colombian Trade Minister Says Administration Lacks Benchmarks for FTA, 23.04; Inside U. S. Trade (2010): Finance, Ways and Means Members Call for Action on Pending FTAs, 11.06.

29 Inside U. S. Trade (2010): Obama Eyes Push on Panama, Colombia FTAs after Elections, 01.10. 
leadership diverged and, therefore, the domestic win-set shrank. Because the House, which had the toughest stance on free trade agreements under Democratic leadership (also compared to the Obama administration), became more pro-free trade with the new Republican majority, it is reasonable to assume that the intersection of the win-sets increased for both FTA negotiations. However, the intersection increased only to a certain degree because it was still constrained by the Obama administration. ${ }^{30}$

With regard to the negotiation with South Korea, the Republicans (in contrast to the Bush administration) neither supported nor opposed renegotiations over automobiles, which is why the ideal points of the Republican-led House and the Obama administration did not diverge as much as in the case of the FTA with Colombia (see below). Shortly after the elections, the Obama administration and South Korean government met for negotiations but did not reach agreement as planned before the G2o summit in Seoul. The Lee government still saw the signed agreement as a new negotiating basis. In this situation, there was a sense in the Obama administration that the negotiations had failed. ${ }^{31}$ But both sides finally came to an agreement in December. In the end,

30 In retrospect, the votes by the 112th Congress regarding the FTAs with Colombia and South Korea and the bill to extend the Generalized System of Preferences and Trade Adjustment Assistance support the assessment of the election effects on the preference changes of Congress. The House passed the United States-Colombia Trade Promotion Agreement Implementation Act (H.R. 3780) by a vote of 262-167. 231 (9) Republicans and 31 (158) Democrats voted for (against) the bill. 63 of the 64 Republicans who replaced Democrats of the 111th Congress voted for the bill, while all four Democrats who replaced a Republican voted with nay. The Senate passed the bill on a vote of 66-33. 44 Republicans and 21 Democrats voted for the bill, while 2 vs. 30 voted against it. The five Republican senators who replaced a Democratic one voted for the FTA. The House passed the United States-South Korea Promotion Agreement Implementation Act (H.R. 3080) by a vote of 278-151. 219 Republicans and 59 Democrats voted for the bill, while 21 vs. 130 voted against it. 59 of the 64 Republicans who replaced a Democrat and three of four Democrats who replaced a Republican voted for the bill. The Senate passed the bill on a vote of 83-15. 45 Republicans and 37 Democrats voted with yea, while 1 vs. 14 voted nay. All five Republicans who replaced a Democratic senator voted for the FTA. Furthermore, Congress passed a bill that extended the Generalized System of Preference and included an extension of the Trade Adjustment Assistance (H.R. 2832). The Senate passed the bill by a vote of 70-27. $5_{1}$ Democrats and 17 Republicans voted for the bill, while 0 vs. 27 voted against it. Three of the five Republican senators who replaced a Democratic one voted with Yea. The House passed the bill on a vote of 307-122. 189 Democrats and 118 Republicans voted for the bill, while 0 vs. 122 voted against it. 36 of the 64 Republicans who replaced a Democrat voted with nay, while all four Democrats who replaced a Republican voted with yea. Interview with senior staff member of Congress, 14.05.2012, Washington DC. 
the Lee government made concessions related to automobiles but received side payments for agricultural products, IPRs and visa provisions (Cooper et al. 2011: 5-6). ${ }^{32}$ In February 2011, both executives signed three supplementary agreements. Furthermore, the Obama administration waived its demand for negotiations over the beef import ban (Cooper et al. 2011: 21-23; Platzer 2011: 4-5; Barbour 2011: 2-4). ${ }^{33}$

Regarding the FTA negotiations with Colombia, the election increased the programmatic distance between the Obama administration and the Senate on the one hand and the Republican-led House on the other, because Republicans were skeptical towards stronger labor standards. Yet the House, which had the toughest stance in the conflict over labor standards until then, was now led by Republicans and therefore lost its blocking position in the FTA negotiations with Colombia. The changes of TPA rules and the often-repeated demand for, but not realized, creation of a demand list by House Democrats indicate that the win-set for the FTA with Colombia had dissolved completely after the Democrats took over Congress in 2006. Hence, even if the conflict over labor standards constrained the domestic win-set in the United States, it can be assumed that the elections in 2010 recreated an intersection of the win-sets that might have been previously dissolved.

After the accession of the new Congress in January, the deadlocked negotiations with Colombia finally regained momentum. ${ }^{34}$ Despite the election of the Republicans, who gave the FTA negotiations higher priority, the pressure to find a deal increased in February after Republicans and Democrats could not agree on an extension of the Andean Trade Promotion and Drug Eradication Act (ATPDEA), which gave Colombia preferential access to the Us market to create alternatives for coca production (Villarreal 2011: 27). ${ }^{35}$ Thus, the nonextension of ATPDEA was hurting all parties, because it contradicted the goal of fighting coca production and drug trafficking. In March, both countries continued the negotiations and the Obama administration for the first time presented a list with concrete demands. A month later, both countries agreed on an action plan related to labor rights. Colombia committed to improve worker rights and strengthen law enforcement to lower the rate of homicides against

32 Inside U. S. Trade (2010): U.S., Korea Strike Supplemental FTA Deal on Autos, Get Wide Support, 03.12.

33 Inside U. S. Trade (2011): Baucus Supports KORUS in Light of U.S., not Korean, Beef Commitments, 05.05 .

34 Interview with senior staff member of Congress, 14.05.2012, Washington DC.

35 Inside U. S. Trade (2011): ATPDEA Supporters Stress Link to Drug Eradication in Colombia, 18.03. 
trade unionists. While some Democrats still opposed the FTA, the Obama administration and a large enough group of Democrats now supported the agreement (Villarreal 2011: 27). ${ }^{36}$ After solving the conflict over the sequence of the pending FTAs, Congress approved all bills separately but at the same time in October 2011. ${ }^{37}$ In November, the Saenuri party, which had the absolute majority, ratified the FTA despite strong opposition and turmoil in the South Korean national assembly. The FTAs entered into force in spring 2012 (Cooper et al. 2011: 44-45).38

The Republican takeover of the House after the midterm elections decreased the domestic win-set. However, the Democratic-led House that was the main stumbling block for the FTAs became more pro-free trade under the Republican majority. Thus, it can be assumed that the intersection of win-sets increased actually to a certain degree in both FTA negotiations. Furthermore, the FTAs had a higher priority for the Republicans, who pushed the negotiations, although the Obama administration and Democrats in Congress insisted on renegotiations about labor standards and market access for automobiles. In the case of Colombia, it is likely that the intersection of win-sets just reappeared as the result of the preference change in Congress even if the intersection was still small. Yet, no intensive conflict arose at the international level because the Colombian government was aware of the small intersection of win-sets and was willing to make the necessary concessions regarding labor reforms. In contrast, the negotiations with South Korea were heated and close to failure because the South Korean government still saw the already signed agreement as the basis of the current negotiations. In the end, the Obama administration was willing to give concessions in other areas to obtain its demands regarding market access for automobiles.

36 Inside U. S. Trade (2011): U.S., Colombia Agree to Labor Action Plan Aimed at Advancing FTA, o6.04; Inside U. S. Trade (2011): Levin Cautious on Colombia Action Plan, Observers Mixed on Response, 08.04; The Associated Press (2011): "Us, Colombia Reach Deal on Key Free Trade Pact," 06.04.

37 Inside U. S. Trade (2011): Congressional Staff Close to Deal on How to Move Forward FTAs, TAA, 28.07; Inside U. S. Trade (2011): Reid, McConnell Endorse Post-Recess FTA/TAA Action; Details Unresolved, 05.08; Inside U. S. Trade (2011): House Passes Three FTAs, Extension of Lapsed TAA/GSP Programs, 12.10; Inside U. S. Trade (2011): Senate Approves Three FTAs, with Korea Getting the Strongest Vote, 14.10.

38 Inside U. S. Trade (2011): Korean Ruling Party Passes FTA Unilaterally; Democratic Party Objects, 25.11; Sang-hun, Choe (2011): "Seoul Votes a Chaotic Yes to Free Trade with us," New York Times, 22.11; Sun-young, Lee (2011): "Seoul FTA Wrangling Heats up outside Assembly," Korea Herald, o6.11. 


\section{Considering Preference Changes in Two-level Games}

The analytical narratives employed above question the classical hypotheses of the two-level game that a smaller domestic win-set increases the risk of a negotiation breakdown but creates a bargaining lever vis-à-vis the foreign country. And even if the narratives conform with the hypotheses in some situations, the causal mechanism such as transaction costs or external constraints used to explain the correlation between the win-set and the chances of cooperation or distribution of gains often seem to be insufficient or inapplicable. Yet, instead of rejecting the two-level game, the empirical insights will be used below to improve the two-level game not only for a better understanding of the narratives, but also to make the two-level game a more useful tool to analyze preference changes in international negotiations. The aim is to derive hypotheses and causal mechanisms that explain the effects of all preference changes due to elections, including those explained and not explained by the classical hypotheses. While the empirical focus of this study is on preference changes caused by elections, the theoretical part considers preference changes in general. The analytical narratives highlight two aspects that might improve the explanatory power of the two-level game. First, preference changes have an impact on the probability of cooperation and distribution of gains by affecting the intensity of conflicts. Second, the already achieved bargaining results before a preference change can transform the perception of conflicts, which again affects the probability of cooperation and distribution of gains. Therefore, in a first step, social conflicts will be integrated into the two-level game. The main focus here is on the question of how the changing size of a win-set affects the intensity of conflicts. In a second step, it will be discussed how already achieved bargaining results can transform the perception of conflicts.

\section{Social Conflicts and Preference Changes}

According to the classical hypotheses of the two-level game, the chance of cooperation depends on the size of the win-sets and, therefore, the probability that the win-sets overlap (Putnam 1988) and possible external constraints or transaction costs are surpassed (Tsebelis 2002). While the two-level game assumes conflicts of interests, it does not take into account social conflicts and their intensity. Conflict intensity can be defined as the difference between the value of an outcome if an actor wins and the value of that outcome if the opponent wins (Deutsch 1973: 283). In this case, as Janusch (2016) has shown, it can be argued that the perceived size of the intersection of the domestic win-sets determines the conflict intensity. The larger the perceived intersection of win-sets, the higher the intensity of conflicts, and therefore the more 
likely negotiations are to break down. The reason for this is that negotiators who are aware of the larger bargaining space and intersection of win-sets respectively become more risk seeking and more often use threats to push for a favored outcome. Public threats often limit the bargaining space because they impose costs ex post for a negotiator if she or he should back down from the threat. These costs can take the form of reputational losses or audience costs. According to theories of reputation, negotiators suffer a reputational loss if they back down from their threats and demands, and will lose bargaining power in future negotiations (Miller 2003; Guzman 2008). According to the audience costs argument, the domestic audience or electorate will punish a government for inconsistency between words and deeds if it backs down from threats or demands (Fearon 1995, 1997; Tarar \& Leventoğlu 2013; Chaudoin 2014). ${ }^{39}$ Thus, threats can start a conflict dynamic, artificially reduce the bargaining space and, therefore, imply the risk of dissolving the intersection of the win-sets completely.

Interestingly, based on this argument, if the programmatic distance between the actors decreases in the event of a preference change, and therefore the expected intersection of the win-sets increases, negotiations are more likely to fail because of higher conflict intensity. Conversely, the smaller the intersection of the win-sets becomes due to preference changes - as long as it does not dissolve completely - the less likely it is that negotiations will break down. The reason for this is that if negotiators are aware of the smaller bargaining space, they will forego the use of threats that might risk a breakdown as a consequence of overly high demands (Janusch 2016). Following these arguments, the Schelling conjecture that a smaller domestic win-set can be a bargaining advantage for the domestic executive vis-à-vis the foreign counterpart still applies. However, as Hammond and Prins (2006) have already shown, the location of the ideal points and status quo determines who will profit from domestic constraints. Thus, the Schelling conjecture can work also in favor of foreign actors or domestic actors other than the executive. For example, in the case of the FTA negotiations, the hawkish position of Democrats in Congress created a bargaining leverage for the Bush administration vis-à-vis the Colombian government to push for stronger labor provisions. Yet, this leverage was not in the interest of the Bush administration.

The above arguments about social conflicts can help to explain developments in the FTA negotiations with Colombia. While the smaller intersection of win-sets prevented the rise of intensive social conflicts, the Colombian government was willing to make more concessions vis-à-vis the United States to reach an agreement. However, the case neither supports nor rejects the

For critiques of the audience costs argument see Clare (2007); and Weeks (2008). 
proposition that a larger intersection of win-sets causes a higher conflict intensity and therefore increases the risk of a breakdown of negotiations. Yet, the modified two-level game helps also to explain the effects of the elections in South Korea that increased the intersection of win-sets and led to a higher conflict intensity regarding the dispute over beef. However, domestic protests and not the negotiators themselves triggered the increasing conflict intensity, which is why the example supports the causal mechanism of the hypothesis only to a certain degree. On the contrary, the us elections with regard to the FTA negotiations with South Korea contradict the hypotheses made above, because the smaller win-set and resulting intersection of win-sets led to higher conflict intensity and gave the United States no additional bargaining leverage. However, the above conclusions are based only on the changing size of the win-sets and their intersection as a result of preference changes. When considering the achieved bargaining results and perception of the status quo, the difference between both cases can be explained.

\section{Achieved Bargaining Results and Preference Changes}

In addition to the size of the win-sets, changing preferences due to elections or other events can also cause a change of perception of the status quo and social conflicts. If negotiations are seen as a dynamic process, it is reasonable to hypothesize that the further negotiations have advanced, the more negotiators will perceive bargaining results already achieved as the new status quo. This will be the case especially if there is a change of government during the ratification process and one of the negotiating parties demands renegotiations of the already signed agreement. This argument resembles the anchoring effect (Tversky \& Kahneman 1974). The anchoring effect describes a cognitive bias according to which actors rely too heavily on the first piece of information so-called anchor - when making decisions. In the case described above, yet, it is not the first piece of information that serves as anchor, but arrangements that are taken as final deals such as signed but not ratified international treaties.

On the one hand, when the preference change decreases the intersection of the win-sets in favor of the domestic government whose preferences changed, the foreign government is more likely to see the already achieved bargaining results as a new status quo. In this case, previous conflicts of distribution or positive sum games transform into goal conflicts or zero sum games. The foreign government will see any concession as a unilateral gift, for which reason it rejects renegotiations and will fight harder to avoid losses. Thus, the conflict intensity increases and, thereby, the risk that the negotiations break down also rises. Furthermore, even if the intersection of the win-sets decreases to the advantage of the domestic government, it has no effect on the distribution of gains when the foreign government perceives a zero sum game. This 
argument is supported by the prospect theory, according to which actors are more risk-accepting in domains of loss and more risk-averse in domains of gain (Kahneman \& Tversky 1979; Tversky \& Kahneman 1992). For example, after the midterm elections in 2006, the win-set of the United States decreased to the disadvantage of the Korean government. Yet, the Korean government saw the signed agreement as an anchor and could push for mutual concessions.

On the other hand, when the preference change increases the intersection of the win-sets in favor of the foreign government, the domestic government is more likely to use the achieved bargaining results as anchor. In this case, the domestic government will perceive a previous positive sum game as zero sum game, for which reason the conflict intensity and risk of a negotiation breakdown rise. Furthermore, the domestic government will lose no bargaining leverage when it perceives the bargaining situation as a zero sum game, although the intersection of the win-sets actually increases to its disadvantage. For example, after the elections in South Korea, the Korean government did not lose any bargaining leverage, although the domestic win-set increased to its disadvantage. Thus, independently if the size of the intersection of win-sets decreases or increases, when one side takes the already achieved bargaining results as an anchor, the chances for cooperation sink and no party receives a bargaining advantage as a result of the changing size of a win-set.

The consideration of already achieved bargaining results can help to explain the differences between the FTA negotiations with Colombia and South Korea. In the former negotiations, the Colombian government did not take the already achieved bargaining results as an anchor and was willing to make more concessions regarding labor provisions, because it was aware of the smaller intersection of win-sets. On the contrary, in the latter one, the Korean government saw the signed agreement as a new status quo, for which reason the conflict transformed into a zero sum game. As a consequence, the risk of a negotiation breakdown increased, although the negotiations could be concluded successfully at the end. Furthermore, the Korean government could push for mutual concessions and did not lose bargaining leverage, although the domestic constraints of the United States increased after elections and the win-set of South Korea increased as a result of its elections.

\section{Conclusions}

In new liberalism and other rationalistic approaches, actors' preferences in negotiations are often assumed to be fixed. And even if preference changes 
are considered, most scholars analyze the altered bargaining situation after a preference change as if it were a new case starting again from the beginning. Hence, already arisen conflicts, used bargaining tactics and achieved bargaining results in continuous negotiations are left aside. Based on these assumptions, new liberals argue that a higher programmatic distance between actors and, therefore, smaller win-set as the result of a preference change reduce the probability of cooperation. Furthermore, the domestic constraints resulting from a smaller win-set can increase the bargaining lever of a country at the international level. Yet, the analytical narratives of the us trade negotiations with South Korea and Colombia question these classical hypotheses and their causal mechanism and emphasize two aspects that have been neglected in two-level games (as well as veto player theory and rationalist bargaining theory). First, preference changes impact the probability of cooperation and distribution of gains by affecting the intensity of conflicts. Second, already achieved bargaining results before a preference change can transform the perception of conflicts after a preference change, which affects the probability of cooperation and distribution of gains.

Based on the empirical insights, social conflicts and actors' perception of already achieved bargaining results as simple ways to assume ongoing negotiations were integrated in the two-level game. According to the hypothesis derived from the modified two-level game, smaller win-sets and their intersection as a result of preference changes can mitigate conflicts of distribution and make cooperation more likely, as long as the intersection does not dissolve and the negotiators are aware of the smaller bargaining space. Yet, when negotiators see already achieved results as a new status quo and use them as anchor, conflicts of distribution or positive sum games can transform into goal conflicts or zero sum games, and cooperation will become more difficult to reach. Because actors fight harder to avoid losses than to receive gains, the Schelling conjecture that domestic constraints can be used as a bargaining lever vis-à-vis a foreign country no longer holds if foreign actors perceive a zero sum game.

Even if the modifications of the two-level game increase the complexity of the theoretical approach, the inclusion of a basic definition of social conflicts and simple simulation of ongoing negotiations by considering already achieved bargaining results still tries to keep the theory parsimonious. Furthermore, the explanatory power gained by the derived hypotheses and the better understanding of the analytic narratives compensate for the moderate loss in parsimony. The theoretical and empirical insights are interesting in terms of improving not only New Liberalist theories but also many other quite disparate rationalistic approaches, such as bargaining theory and veto player theory. 


\section{References}

Barbour, Emily C. (2011). "Trade Promotion Authority and the U.S.-South Korea Free Trade Agreement." CRS Report for Congress, 02.03.

Bates, Robert H., Avner Greif, Margaret Levi, Jean-Laurent Rosenthal, and Barry Weingast (1998). Analytic Narratives. Princeton: Princeton University Press.

Bates, Robert H., Avner Greif, Margaret Levi, Jean-Laurent Rosenthal, and Barry Weingast (2000). "The Analytical Narrative Project." American Political Science Review 94, 3: 696-702.

Bearce, David H., Katharine Floros and Heather McKibben (2009). "The Shadow of the Future and International Bargaining: The Occurrence of Bargaining in a ThreePhase Cooperation Framework." The Journal of Politics 71, 2: 719-732.

Beittel, June S. (2011). “Colombia: Issues for Congress." CRS Report for Congress, 18.03 .

Bohara, Alok K, Alejandro Camargo, Therese Grijalva and Kishore Gawande (2005). "Fundamental Dimensions of U.S. Trade Policy." Journal of International Economics 65, 1: 93-125.

Bradley, Richard (2009). "Becker's Thesis and Three Models of Preference Change." Politics, Philosophy \& Economics 8, 2: 223-242.

Carter, Ralph G. and Lorraine Eden (1999). “Who Makes U.S. Trade Policy?” International Trade Journal 13, 1: 53-99.

Chapman, Terrence L., Johannes Urpelainen and Scott Wolford (2013). "International Bargaining, Endogenous Domestic Constraints, and Democratic Accountability." Journal of Theoretical Politics 25, 2: 260-283.

Chaudoin, Stephen (2014). "Promises or Policies? An Experimental Analysis of International Agreements and Audience Reactions." International Organization 68, 1: $235^{-256 .}$

Clare, Joe (2007). "Domestic Audiences and Strategic Interests." Journal of Politics 69, 3: $732-745$.

Cooper, William H., Mark Manyin, Remy Jurenas and Michaela Platzer (2011). "The Proposed U.S.-South Korea Free Trade Agreement (KORUs FTA: Provisions and Implications." CRS Report for Congress, 24.03.

Deutsch, Morton (1973). The Resolution of Conflict. Constructive and Destructive Processes. New Haven: Yale University Press.

Dietrich, Franz and Christian List (2011). "A Model of Non-Informational Preference Change." Journal of Theoretical Politics 23, 2: 145-164.

Dorussen, Han and Kyriaki Nanou, 2006). "European Integration, Intergovernmental Bargaining and Convergence of Party Programmes." European Union Politics 7, 2: $235^{-256 .}$ 
Downs, George W., David Rocke and Peter Barsoom (1998). "Managing the Evolution of Multilateralism." International Organization 52, 2: 397-419.

Fearon, James D. (1995). "Rationalist Explanations for War." International Organization 49, 3: 379-414.

Fearon, James D. (1997). "Signaling Foreign Policy Interests: Tying Hands versus Sinking Costs." Journal of Conflict Resolution 41, 1: 68-90.

Frye, Timothy and Edward Mansfield (2004). "Timing is Everything: Elections and Trade Liberalization in the Postcommunist World." Comparative Political Studies 37, 4: $371-398$.

Gerber, Elisabeth R. and John Jackson (1993). "Endogenous Preferences and the Study of Institutions." American Political Science Review 87, 3: 639-656.

Guzman, Andrew T. (2008). How International Law Works: A Rational Choice Theory. New York: Oxford University Press.

Hammond, Thomas H. and Brandon Prins (2006). "Domestic Veto Institutions, Divided Government, and the Status Quo: A Spatial Model of Two-Level Games with Complete Information." in Robert Pahre, editor, Democratic Foreign Policy Making. Problems of Divided Government and International Cooperation. New York: Palgrave Macmillan, 21-82.

Hausman, Daniel M. (2011). "Mistakes about Preferences in the Social Sciences." Philosophy of the Social Sciences 41, 1: 3-25.

Hiscox, Michael J. (1999). "The Magic Bullet? The RTAA, Institutional Reform, and Trade Liberalization." International Organization 53, 4: 669-698.

Hug, Simon and Thomas König (2002). "In View of Ratification. Governmental Preferences and Domestic Constraints at the Amsterdam Intergovernmental Conference." International Organization 56, 2: 447-476.

Iida, Keisuke (1993). "When and How Do Domestic Constraints Matter? Two-Level Games with Uncertainty." Journal of Conflict Resolution 37, 3: 403-426.

Iida, Keisuke (1996). "Involuntary Defection in Two-Level Games." Public Choice 89, 3-4: $283-303$.

Im, Hyejoon and Hankyoung Sung (2011). "Empirical Analyses of U.S. Congressional Voting on Recent FTA." The B.E. Journal of Economic Analysis \& Policy 11, 1).

Ishiguro, Kaoru (2016). “TPP Negotiations and Political Economy Reforms in Japan's Executive Policy Making: A Two-Level Game Analysis." International Relations of the Asia-Pacific 17, 2: 171-201.

Janusch, Holger (2015a). Das Scheitern internationaler Verhandlungen. Eine vergleichende und qualitative Analyse der US-Handelspolitik. Wiesbaden: vs Verlag für Sozialwissenschaften (Globale Politische Ökonomie).

Janusch, Holger (2015b). "Labor Standards in U.S. Trade Politics." Journal of World Trade 49, 6: 1047-1071. 
Janusch, Holger (2016). "The Breakdown of International Negotiations: Social Conflicts, Audience Costs, and Reputation in Two-Level Games." International Negotiation 21, 3: 495-520.

Ju, Jinyul (2009). "Getting Democratic Legitimacy for the Korea-U.S. Free Trade Agreement." Korean Journal of International Economic Law 7, 1: 139-159.

Kahneman, Daniel and Amos Tversky (1979). "Prospect Theory: An Analysis of Decision under Risk." Econometrica 47, 2: 263-291.

Karol, David (2000). "Divided Government and U.S. Trade Policy. Much Ado About Nothing?" International Organization 54, 4: 825-844.

Kim, Min-hyung (2015). "Theorizing National Preference Formation." Cambridge Review of International Affairs: 1-19.

Koenig-Archibugi, Mathias (2004). "Explaining Government Preferences for Institutional Change in EU Foreign and Security Policy." International Organization 58, 1: 137-174.

König, Thomas (2006). "The Scope for Policy Change after the 2005 Election: Veto Players and Intra-Party Decision Making." German Politics 15, 4: 520-532.

Koo, Min G. and Whasun Jho (2012). "Linking Domestic Decision-Making and International Bargaining Results: Beef and Automobile Negotiations between South Korea and the United States." International Relations of the Asia-Pacific 13, 1: 65-93.

Lohmann, Susanne (1993). "Electoral Cycles and International Policy Cooperation." European Economic Review 37, 7: 1373-1391.

Mansfield, Edward D., Helen Milner and B. Peter Rosendorff (2002). "Why Democracies Cooperate More: Electoral Control and International Trade Agreements." International Organization 56, 3: 477-513.

Martin, Andrew D. and Kevin Quinn (2007). "Assessing Preference Change on the US Supreme Court." Journal of Law, Economics, and Organization 23, 2: 365-385.

Mertha, Andrew and Robert Pahre (2005). "Patently Misleading: Partial Implementation and Bargaining Leverage in Sino-American Negotiations on Intellectual Property Rights." International Organization 59, 3: 695-729.

Miller, Gregory D. (2003). "Hypotheses on Reputation. Alliance Choices and the Shadow of the Past." Security Studies 12, 3: 40-78.

Milner, Helen V. (1997). Interests, Institutions, and Information: Domestic Politics and International Relations. Princeton, NJ: Princeton University Press.

Milner, Helen V. and B. Peter Rosendorff (1997). "Democratic Politics and International Trade Negotiations. Elections and Divided Government as Constraints on Trade Liberalization." Journal of Conflict Resolution 41, 1: 117-146.

Mo, Jongryn (1994). "The Logic of Two-Level Games with Endogenous Domestic Coalitions." Journal of Conflict Resolution 38, 3: 402-422. 
Moravcsik, Andrew (1997). "Taking Preferences Seriously: A Liberal Theory of International Politics." International Organization 51, 4: 513-553.

Moravcsik, Andrew (1998). The Choice for Europe: Social Purpose and State Power from Messina to Maastricht. Ithaca, NY: Cornell University Press.

Moravcsik, Andrew and Frank Schimmelfennig (2009). "Liberal Intergovernmentalism." in Antje Wiener and Thomas Diez, editors, European Integration Theory. Oxford: Oxford University Press: 67-87.

Morrow, James D. (1991). "Electoral and Congressional Incentives and Arms Control." Journal of Conflict Resolution 35, 2: 245-265.

Olson, Mancur (1965). The Logic of Collective Action: Public Goods and the Theory of Groups. Cambridge, MA: Harvard University Press.

Pahre, Robert (1997). "Endogenous Domestic Institutions in Two-Level Games and Parliamentary Oversight of the European Union." Journal of Conflict Resolution 41, 1: 147-174.

Pahre, Robert (2004). "House Rules: Institutional Choice and United States Trade Negotiations." Conflict Management and Peace Science 21, 3: 195-213.

Pahre, Robert (2005). "Formal Theory and Case-Study Methods in EU Studies." European Union Politics 6, 1: 113-146.

Pahre, Robert (2006). "Divided Government and International Cooperation: An Overview," in Robert Pahre, editor, Democratic Foreign Policy Making: Problems of Divided Government and International Cooperation. New York: Palgrave Macmillan: $1-19$.

Platzer, Michaela D. (2011). "Pending U.S. and EU Free Trade Agreements with South Korea. Possible Implications for Automobile and Other Manufacturing Industries." CRS Report for Congress, 14.01.

Putnam, Robert D. (1988). "Diplomacy and Domestic Politics. The Logic of the TwoLevel Game." International Organization 42, 3: 427-460.

Ragin, Charles C. (1987). The Comparative Method: Moving Beyond Qualitative and Quantitative Strategies. Berkeley: University of California Press.

Rankin, David M. (2006). "Featuring the President as Free Trader. Television News Coverage of U.S. Trade Politics." Presidential Studies Quarterly 36, 4: 633-659.

Rizvi: Abu Turab (2001). "Preference Formation and the Axioms of Choice." Review of Political Economy 13, 2: 141-159.

Schelling, Thomas C. (1960). The Strategy of Conflict. Cambridge, MA: Harvard University Press.

Smith, Alastair and David Hayes (1997). "The Shadow of the Polls: Electoral Effects on International Agreements." International Interactions 23, 1: 79-108.

Sussman, Glen and Byron Daynes (1995). "The Impact of Political Ideology on Congressional Support for Presidential Policy Making Authority: The Case of the Fast Track." Congress \& the Presidency 22, 2: 141-153. 
Tabellini, Guido (1990). "Domestic Politics and the International Coordination of Fiscal Policies." Journal of International Economics 28, 3-4: 245-265.

Tarar, Ahmer (2005). "Constituencies and Preferences in International Bargaining." Journal of Conflict Resolution 49, 3:383-407.

Tarar, Ahmer and Bahar Leventoğlu (2013). "Limited Audience Costs in International Crises." Journal of Conflict Resolution 57, 6: 1065-1089.

Trampusch, Christine (2014). "Why Preferences and Institutions Change: A Systematic Process Analysis of Credit Rating in Germany." European Journal of Political Research 53, 2: 328-344.

Trumbore, Peter F. (1998). "Public Opinion as a Domestic Constraint in International Negotiations: Two-Level Games in the Anglo-Irish Peace Process." International Studies Quarterly 42, 3: 545-565.

Tsebelis, George (2002). Veto Players: How Political Institutions Work. New York: Russell Sage Foundation.

Tversky, Amos and Daniel Kahnemanm (1974). "Judgment under Uncertainty: Heuristics and Biases." Science 185, 4157): 1124-1131.

Tversky, Amos and Daniel Kahneman (1992). "Advances in Prospect Theory: Cumulative Representation of Uncertainty." Journal of Risk and Uncertainty 5, 4: 297-323.

Villarreal, M. Angeles (2011). "Proposed U.S.-Colombia Free Trade Agreement. Background and Issues." CRS Report for Congress, 12.04 .

Weeks, Jessica L. (2008). "Autocratic Audience Costs: Regime Type and Signaling Resolve." International Organization 62, 1: 35-64.

Weller, Nicholas (2009). "Trading Policy: Constituents and Party in U.S. Trade Policy." Public Choice 141, 1/2: 87-101. 